This article was downloaded by: [KU Leuven University Library]

On: 20 June 2014, At: 04:22

Publisher: Routledge

Informa Ltd Registered in England and Wales Registered Number: 1072954 Registered

office: Mortimer House, 37-41 Mortimer Street, London W1T 3J H, UK

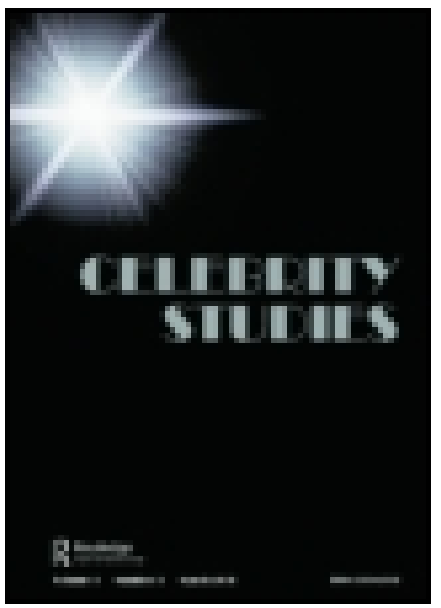

\title{
Celebrity Studies
}

Publication details, including instructions for authors and subscription information:

http:// www. tandfonline.com/loi/ rcel20

\section{It takes two to tango: the relationship between the press and celebrities in Belgium}

\author{
Baldwin Van Gorp ${ }^{a}$ \\ a Institute for Media Studies, KU Leuven, Leuven, Belgium \\ Published online: 09 J un 2014.
}

To cite this article: Baldwin Van Gorp (2014): It takes two to tango: the relationship between the press and celebrities in Belgium, Celebrity Studies, DOI: 10.1080/ 19392397.2014.920209

To link to this article: http:// dx.doi.org/ 10.1080/ 19392397.2014.920209

\section{PLEASE SCROLL DOWN FOR ARTICLE}

Taylor \& Francis makes every effort to ensure the accuracy of all the information (the "Content") contained in the publications on our platform. However, Taylor \& Francis, our agents, and our licensors make no representations or warranties whatsoever as to the accuracy, completeness, or suitability for any purpose of the Content. Any opinions and views expressed in this publication are the opinions and views of the authors, and are not the views of or endorsed by Taylor \& Francis. The accuracy of the Content should not be relied upon and should be independently verified with primary sources of information. Taylor and Francis shall not be liable for any losses, actions, claims, proceedings, demands, costs, expenses, damages, and other liabilities whatsoever or howsoever caused arising directly or indirectly in connection with, in relation to or arising out of the use of the Content.

This article may be used for research, teaching, and private study purposes. Any substantial or systematic reproduction, redistribution, reselling, loan, sub-licensing, systematic supply, or distribution in any form to anyone is expressly forbidden. Terms \& Conditions of access and use can be found at http://www.tandfonline.com/page/termsand-conditions 


\title{
It takes two to tango: the relationship between the press and celebrities in Belgium
}

\author{
Baldwin Van Gorp* \\ Institute for Media Studies, KU Leuven, Leuven, Belgium
}

(Received 14 July 2012; accepted 29 April 2014)

\begin{abstract}
The objective of this paper is twofold. The first aim is to examine the characteristics of the celebrity press in Flanders (the Dutch-speaking part of Belgium) in comparison with the foreign celebrity press. The second aim is to characterise the interaction between local celebrities and journalists, as conflict, cooperation or negotiation. To this end, a content analysis was performed on the three Flemish celebrity magazines and leading journalists, editors and celebrities were interviewed. The results show that, first, the majority of the articles cannot be typified as 'gossip' stories and, second, most journalists and celebrities label the mutual relationship as one of cooperation and negotiation. However, as a result of market competition, Flemish celebrity journalists are increasingly pushing ethical boundaries. The paper discusses how the press can both make and break a celebrity's career. Specifically, ordinary people who rise to unexpected fame through their participation in reality shows have very limited negotiation leverage.
\end{abstract}

Keywords: celebrity press; celebrity journalists; magazines; reality television; Belgium

\section{Introduction}

Although celebrity is a global phenomenon, it also has an important culture-specific, local dimension. This paper concentrates on the situation in Flanders, the Dutch-speaking part of Belgium. The restriction to a specific, small market with a limited number of news outlets and a conveniently small number of local celebrities offers a twofold advantage: this makes it possible, first, to cover the full range of the Flemish celebrity press and, second, to conduct face-to-face interviews with a broad selection of journalists and local celebrities.

Usually, scholars rely on the press to gain insight into celebrity culture but do not directly involve actual celebrities in their research. Cornea $(2008$, p. 118) suggested that avoiding direct contact with celebrities themselves stems from a desire to maintain a critical distance. Some believe that interviews with people who work in the media are superficial and bring no new or alternative insights (Mills 2008, p. 150). Furthermore, celebrities may see interviews as a 'performance', a crucial part of presenting themselves as a commodity (Curnutt 2009, p. 254). Consequently, the gathered interview data could be invalid. Nevertheless, we considered the possibility of talking to certain celebrities in person as an opportunity to gain a better understanding of the relationship between the popular press and Flemish celebrities (cf. Turner 2010). However, we were only able to consider how celebrities and journalists express their experiences to an outsider, without witnessing their actual conduct.

*Email: baldwin.vangorp@soc.kuleuven.be 
Gaining insight into the relationship between celebrities and the press is interesting because of the mutual dependence between journalists and celebrities (Turner 2004, Marshall 2005). On the one hand, the celebrity press, as a crucial part of the celebrity industry, helps celebrities attain star status and increases their visibility to their key audiences. On the other hand, by giving journalists access to their private lives, celebrities help boost magazine sales.

The question remains, however, whether journalists and celebrities are really on an equal footing with each other. To a certain extent, journalists are in the weaker position if they are unable to obtain information directly from the celebrities - who are not in the habit of organising press conferences on their private lives - and have to get hold of information in other ways. On the other hand, celebrities depend on the media for free publicity, particularly as the readers of glossy celebrity magazines are usually their target audience. In exchange, they are expected to allow the press and the public a glimpse of their private lives.

The alliance between celebrity and journalism has often been condemned as the 'less noble side of journalistic practice' (Marshall 2005, p. 19). One of the main criticisms concerns the disproportionate attention for apparently 'trivial' news on celebrities such as Paris Hilton or Britney Spears, even in the more serious press. The celebrities, for their part, also frequently lash out at the press, particularly at intrusive paparazzi, who are occasionally punched or have their cameras smashed by angry stars.

A number of complaints and court cases filed against the Flemish popular press by celebrities form the background of this study. It seems as if the relationship between local celebrities and the popular press in Flanders has become strained in recent years. For instance, in a press release issued by press agency Belga (18 September 2009), the lawyer acting for Kelly Pfaff, daughter of Jean-Marie Pfaff, former goalkeeper of the national soccer team, described an article that had appeared about his client as a 'totally one-sided, utterly untruthful and largely libellous article, lacking any moral and legal decency and exceeding the boundaries of the acceptable'. In the wake of the suicide of singer and television hostess Yasmine - which was blamed on her lesbian ex-partner (winner of reality show The Mole [De Mol] (2000)) by magazine Dag Allemaal - crooner Helmut Lotti and former MTV vee-jay and television personality Marcel Vanthilt denounced the popular press for lacking any sense of moral decency (De Foer 2009). Lotti and Vanthilt therefore appealed to all local celebrities to stop talking to the gossip press. Both the celebrity press and the mainstream press eagerly covered these conflicts, which fit perfectly into the 'media as circus' news frame, whereby the functioning of one medium is discussed by another medium and whereby they distance themselves from it (see Zoch 2001).

In Flanders, the label 'gossip press' is used to refer to three weeklies - Dag Allemaal, Story and TV Familie - all of which have excellent sales figures in spite of appeals for a boycott. Dag Allemaal is Belgium's best-selling publication, with an average circulation of 422,067 copies a week in 2010 (CIM 2011). This market leader is published by De Persgroep Publishing, Flanders biggest (family-owned) media conglomerate. Story, published by Finnish-owned Sanoma Magazines Belgium, is Dag Allemaal's principal competitor and ranks fourth in the top 10 of Flemish magazines, with 164,318 copies a week. TV Familie, also published by De Persgroep Publishing, ranks sixth, with 121,434 copies a week.

In this study, the term 'celebrity press' rather than 'gossip press' is preferred, as gossip has a number of specific characteristics that may not be apparent in our study (Rosenbaum and Subrin 1963, DiFonzo and Bordia 2007). Gossip is evaluative social talk that may contain an element of truth, which refers to the behaviour and actions of other people in their private 
context, sometimes with intimate details. Gossip is often motivated by the intention to hurt someone or to express hostility, which is why it is socially disapproved of. DiFonzo and Bordia (2007), however, indicate that gossiping also has a social function as it strengthens the gossipers' ties with the culture and society they live in.

However, we are not rejecting the category of gossip: this study investigates whether these characteristics of gossip apply to the stories that appear in the Flemish celebrity press. The first objective of this research is therefore to characterise the content of the Flemish celebrity press in comparison with the foreign celebrity press.

In his research into the relationship between journalists and PR practitioners, Charron (1989, p. 43) distinguished three types of interaction: conflict, cooperation, and negotiation. Conflict is a process in which the interests of one party come up against the interests of another. A second type of behaviour is cooperation, in which both actors have shared interests and therefore agree to collaborate. The synthesis of conflict and cooperation, finally, is negotiation, which seeks to reconcile the divergent interests of both parties in accordance with mutually agreed rules of engagement.

The second objective of the present study is to determine which of these three types of interaction - conflict, cooperation or negotiation - characterises the relationship between journalists and celebrities in Flanders.

\section{The history of the Flemish celebrity press}

The history of the Belgian celebrity press has not yet been written, probably because the preferred form of celebrity journalism in Belgium is not the tabloid newspaper, but the magazine (see Ponde de Leon 2002). In fact, there are no tabloid newspapers in Flanders similar to Bild (Germany), The Sun (UK) or the weekly supermarket tabloid The National Enquirer (US). Nevertheless, Hauttekeete (2004) found a trend towards tabloidisation of both content and form in the Flemish newspaper press. After 1991, she noted an increasing coverage of sensational and human interest stories, with an emphasis on drama and negativity, and increased use of photographs and colours. Nowadays, all Flemish newspapers pay attention to local celebrities' private lives, although certain stories only appear in their online version or in a separate 'gossip' section. For example, the Flemish broadsheet De Standaard employs a journalist who is expected to monitor the 'gossip press' and, if relevant, include news items in the paper. The Flemish newspaper devoting most attention to celebrities is Het Laatste Nieuws, but even in this, Flanders' best-selling newspaper, the space dedicated to celebrity news is generally restricted to one page.

Dag Allemaal, Story and TV Familie are the most complete source of celebrity news in Flanders. However, they lack a number of typical tabloid characteristics with regard to content, attention for the extraordinary, sports and scandals (Bird 1992, Sparks 2000, Örnebring and Jönsson 2004, Turner 2004, Conboy 2006), unless celebrities are involved. Internationally, the three magazines can be compared with celebrity magazines such as People and Star in the US and OK! and Reveal in the UK. Dag Allemaal pays more attention to lifestyle and human interest than the other magazines, but only at the back of the magazine and without any references on the cover. TV Familie features more stories about international stars than its competitors, while Story provides greater coverage of royalty news. All three use simple language, in contrast to the cheeky style typically used in tabloids. Furthermore, there is special attention to the visual: every article is accompanied by at least one photograph, although these do not contain offensive material such as nudity (unlike the 'Page Three Girl' in certain British tabloids) or violence. 
All three periodicals originated in the market of television magazines; that is, weekly television listings accompanied by informative articles on television and other entertainment media. Since 1969, two television magazines have dominated the Flemish market: the progressive, relatively highbrow weekly Humo (publishing company Dupuis, later The Press, and recently Humo nv); and the more conservative, unsophisticated weekly $t v$-Ekspres (publishing company Perexma). Both contain articles on local celebrities but, initially at least, the interviews hardly ever touched on the stars' private lives. Instead, they presented a respectful glimpse behind the scenes of the entertainment world with, among other things, background information on television programmes. Since 1975, stories about the private lives of celebrities have been appearing in Story, a weekly published by the Dutch publishing company VNU, as a Flemish edition of the Dutch Story (1974), which modelled itself on the American magazines Star and National Enquirer. However, the editor at that time wanted Story to be 'a friendly and positive magazine, both to the public and the stars [...] I haven't been on trial in 25 years' (Louis van Raak, editor-in-chief Story 1975-2000, personal communication, 18 April 2011).

Dag Allemaal, the magazine that reshaped the Flemish media landscape, appeared on the market in 1984 (published by Sparta, later Magnet Magazines, and since 1993 by De Persgroep). With the launch of VTM, Flanders' first commercial broadcasting station, in 1989 , the magazine evolved into a fully fledged weekly, paying special attention to local celebrities. Its unprecedented success, which continues until today, can be attributed to its direct link with VTM, enabling the magazine to bring exclusive stories on brand-new television celebrities. Together, the broadcasting company and the magazine helped launch the careers of a wide range of local celebrities, to their mutual advantage.

Over the years, however, the journalistic practice of offering celebrities favourable coverage in exchange for their collaboration has been replaced by more negative coverage. In 2001, De Persgroep bought competitor $t v$-Ekspres (in the meantime renamed $T V$ Expres). For a while, $T V$-Expres tried to limit coverage of celebrities' private lives, but this policy turned out to be unsustainable. Gradually, its rival Humo also started publishing occasional interviews with and photographs of local celebrities who would not have received attention in the earlier days, such as soap actors. In 1995, De Persgroep itself introduced a new competitor to Dag Allemaal - TV Familie, a television magazine that also features many short articles on foreign celebrities.

Table 1 compares reader characteristics of the three magazines in the sample with those of Knack, a popular Flemish news magazine aimed at a different segment of the Belgian magazine market. The three celebrity magazines have similar reader profiles. First, over $60 \%$ of their readership is female (CIM 2011). Second, the popular press reaches a large group of retirees and white-collar workers, which is also the case for Knack. Compared with the news magazine, the celebrity magazines are read by a larger proportion of blue-collar workers $(19 \%$ vs. $6 \%)$ and housewives, and a lower proportion of managerial staff. Finally, fewer than $20 \%$ of the readers in the celebrity press market segment have a higher education degree, as compared with $50 \%$ of Knack's readership.

\section{Two sides of the same coin}

To examine the issue from both press and celebrity perspectives, we first performed a content analysis of 12 issues of each of the three magazines. In a second study, we conducted face-to-face interviews with editors-in-chief, celebrity journalists and a series of celebrities included in the content analysis (see Appendix 1). 
Table 1. Readership socio-demographic characteristics (\%) of three Flemish celebrity magazines compared with Knack, a news magazine.

\begin{tabular}{lcccr}
\hline & Dag Allemaal & Story & TV Familie & Knack \\
\hline Gender & & & & \\
$\quad$ Male & 40.9 & 33.2 & 34.4 & 53.6 \\
$\quad$ Female & 59.1 & 66.8 & 65.6 & 46.4 \\
Profession & & & & \\
$\quad$ Retired & 23.5 & 21.7 & 17.3 & 19.6 \\
White-collar worker & 21.7 & 23.5 & 21.8 & 30.4 \\
$\quad$ Blue-collar worker & 19.6 & 16.3 & 19.3 & 6.2 \\
Student & 12.7 & 14.5 & 17.8 & 12.8 \\
Housewife & 7.3 & 7.8 & 7.6 & 4.4 \\
(Executive) management & 4.6 & 6 & 5.6 & 17.9 \\
$\quad$ Other & 10.6 & 10.2 & 10.6 & 8.7 \\
Education level & & & & \\
$\quad$ Primary or lower secondary & 42.5 & 38.7 & 42.8 & 15.1 \\
$\quad$ Higher secondary & 40.8 & 42.7 & 41.8 & 33.5 \\
College or university & 16.8 & 18.5 & 15.4 & 51.4 \\
\hline
\end{tabular}

Source: Data from the Readership Survey 2010-2011, Centrum voor Informatie over de Media (CIM 2011).

For the content analysis, we studied the issues of Dag Allemaal, Story and TV Familie that had appeared between 12 January and 30 March 2010. All articles on local celebrities were analysed, while articles on foreign celebrities, human-interest stories and columns were excluded. This yielded a total of 1054 relevant articles (Dag Allemaal, 454 articles; TV Familie, 309 articles; Story, 291 articles).

We interviewed the editors-in-chief of Story and TV Familie as well as a leading journalist of Dag Allemaal; the editor-in-chief of Dag Allemaal refused to talk to us. We also spoke with one of Story's former editors-in-chief and the main celebrity journalist of the newspaper Het Laatste Nieuws. In addition, we interviewed 14 local celebrities who appeared several times in the three magazines during the research period. The sample was limited to artists and excluded politicians, mainly because there still seems to be some kind of natural dividing line between performing artists and politicians with regard to our research topic. Journalists seem to regard intrusion into politicians' private lives as more unethical and incompatible with journalistic integrity and political impartiality. This became apparent when Story published private text messages by former Prime Minister Yves Leterme in June 2011. The editor-in-chief was severely criticised from every conceivable angle, which suggests that the disclosure of personal information about politicians without their consent is more easily labelled as inappropriate.

\section{Celebrities in various sizes and weights}

Because we wanted to talk to local celebrities from all walks of life, we used a number of typologies (Van Zoonen 1998, Rojek 2001).

There were no 'ascribed celebrities' in our survey sample; that is, celebrities whose fame derives from biological descent, as is the case for the Belgian royal family. Such celebrities are usually inaccessible and it would have been even more difficult for us to contact them than for celebrity journalists. In the category of 'achieved celebrity' (i.e., fame acquired by accomplishments based on special talents or skills), we managed to interview four individuals. 
Next, we looked for 'attributed celebrities': celebrities who used to be known for their talents but now mostly appeared in the media for other reasons (e.g. public drunkenness or relationship problems). At the time of the interview, the six interviewees that we included in this category were not in the spotlight with any professional projects.

Rojek (2001, pp. 20-29) distinguished two additional sub-categories of celebrities with a short-lived career. First, there are 'celetoids'; that is, ordinary people who appear briefly in the media spotlight, such as lottery winners, sports arena streakers and mistresses of public figures. Unlike foreign tabloids, Flemish celebrity magazines traditionally showed no interest in these people, as they adhere strictly to the international concept of the celebrity magazine. They seem to subscribe to Cashmore's adage to cover 'events in the lives of fantastic people rather than fantastic events in the lives of everyday people' (2006, p. 26). However, since the advent of reality television, celebrity journalists have become interested in the ordinary men and women participating in these shows. They are part of Rojek's sub-category of 'celeactors'. This category also includes a range of 'imaginary constructions' from popular culture, such as J.R. from Dallas (1978-1991) and Mulder and Scully from The X-Files (1993-2002). Unlike participants in talent shows like Pop Idol (2003), ${ }^{1}$ the participants in programmes such as Big Brother (2000-2007) or My Restaurant Rules (2009) did not rise to fame because of their talents. Four of our interlocutors belonged to this category.

In general, it was rather easy to obtain permission for the interviews. Of course, some celebrities refused to cooperate with the study. Only in two cases (Natalia Druyts and Wendy Van Wanten) did we first have to convince the manager to get in touch with the celebrity. One manager also insisted on checking the interviews afterwards. In all other cases, the contact with the celebrities was direct and personal. Some celebrities even helped us in contacting their colleagues.

Every interview was conducted face-to-face using a semi-structured interview guide. The interviews lasted at least one hour and took place at the interviewees' homes, their offices or in a cafe. The tape-recorded interviews were transcribed verbatim and were analysed.

The interviews started with a series of open questions about the interviewees' personal experiences with the relationship between Flemish celebrities and the celebrity magazines. Here we asked for specific anecdotes to illustrate the observations. Next, they were asked to characterise and to reflect on the relationship between both parties, also with references to second-hand stories. Only at the very end of the interviews, by way of conclusion, were the celebrities asked to express their views on our conceptual trichotomy; that is, cooperation, conflict and negotiation.

In his study of a reality actor, Curnutt (2009, pp. 254-255) argued that using interviews as a way to gain insight into celebrity raises a methodological dilemma, because the interviews with celebrities are part of their larger 'textual process of self-construction'. The same might be true for journalists too. As a result, the interviews are far more likely to conceal than reveal, according to Curnutt. Therefore, throughout these interviews, the interviewer kept an open mind and dealt sensitively with the harsh prejudices that exist about gossip press and some celebrities. ${ }^{2}$ This established a sense of trust that led to greater openness. However, both journalists and celebrities are familiar with interviewing techniques and know how to avoid interview pitfalls. Therefore, it was ensured that the interviewer would take a sufficiently critical attitude and did not take all answers at face value. Firstly, the author, who had worked as a journalist for the Flemish celebrity press from 1995 to 1999, provided the interviewer with sufficient background information about journalistic practices that were common in that period, so as to have a starting point to gain insight into the current situation. Secondly, the journalists and the celebrities 
were interviewed alternately. Hence, the information obtained during one interview could be used as input for the next interview with a representative of the other group. This allowed the interviewer to take a more critical stance and refer, anonymously, to comments and examples made by other interviewees. For instance, journalists initially denied that they sometimes pay for exclusive news, while a number of celebrities were open about that part of the deal. This focus on incongruencies between the different interviews was part of a strategy to strengthen the validity of the interviews (see Gorden 1992).

\section{The celebrity press is not entirely gossip-driven}

When we systematically compared the magazines with the characteristics of gossip (i.e. the spreading of possibly damaging information about a specific person's private life without his or her consent), we arrived at the following findings.

First of all, the three Flemish celebrity magazines did not report solely on the celebrities' private lives. Just $10 \%$ of the articles dealt with strictly private matters, whereas 33\% focused on celebrities' private lives with references to their public achievements. One-fifth of the articles dealt with strictly professional activities, while $37 \%$ of the articles focused on celebrities' professional activities with references to their private lives. This means that almost three-quarters $(73 \%)$ of the articles included references to celebrities' professional activities, such as CD presentations, performances, a role in a television series or film or participation in a reality programme.

Secondly, a large proportion of the published articles (74\%) consisted of personal interviews with Flemish stars (Dag Allemaal, 81\%; TV Familie, 71\%; Story, 65\%), and the information they provide about their own private lives can hardly be qualified as gossip.

Thirdly, the analysis showed that emotions played an important role in each of the three weeklies: $45 \%$ of the stories dealt with feelings such as happiness, being in love and sad farewells. Positive feelings were expressed as often as negative feelings, although Dag Allemaal was significantly more interested in negative feelings than the other magazines (Dag Allemaal, 53\%; Story, 41\%; TV Familie, 38\%). As a consequence, there is a distinction between negative, harmful stories and positive, favourable ones. Positive stories about a celebrity's personal life (e.g. a wedding or birth) seldom harm their reputation, even if the celebrity did not want to see them covered. As Marshall (2005) observed, positive private stories about celebrities contribute to their status and can generate publicity. However, this may also be true for negative events, which are generally labelled as 'gossip', such as divorce and relational problems. After all, these stories present celebrities as ordinary human beings with problems that readers can relate to (see further Kordon-Lundgreen and Kordon 1976, Roos 1981, Levin and Arluke 1987).

The Flemish magazines do not exclusively focus on negative news. For instance, in stories about family life (41\%), 73\% of the articles take a positive approach; for example, mentioning how the children are doing at school. In sharp contrast to supermarket tabloids such as The National Enquirer and to other foreign weeklies, which contain extensive coverage of celebrities' problems (with regard to female celebrities, they particularly deal with weight issues), the Flemish celebrity press seems balanced towards the positive. This will be explained further below, based on interviews with journalists and celebrities.

\section{A trend toward tabloidisation}

Based on the quantitative analysis, the conclusion is that, strictly speaking, the three Flemish magazines cannot be labelled as gossip magazines. A substantial part of the 
stories concerned professional activities, the majority of the articles were based on interviews with the celebrities themselves and the stories could not usually be regarded as damaging from the celebrities' point of view.

However, when we examined the lead articles more closely, we reached a more nuanced conclusion, namely that the weeklies use a number of practices typical of foreign tabloids and celebrity magazines. These included: first, approaching insiders and people from the celebrities' entourage; second, payment for exclusivity; third, taking interview quotes out of context and, in the case of the cover article, making them more sensational; and fourth, strategically choosing which celebrities to antagonise.

First of all, celebrity journalists regularly try to obtain further information through their network or through persons close to the celebrity, even though most local celebrities can be approached for a face-to-face interview. However, it is precisely for the negative, 'juicier' stories about which celebrities prefer not to talk that the magazines turned to 'insiders', 'a family friend' and other anonymous sources. As appeared from the interviews, in a number of cases other celebrities acted as anonymous sources.

According to the journalists we interviewed, a factor that contributed to the practice of using sources close to the celebrities is that celebrities increasingly want something in return for their collaboration, for both positive and negative stories. This is another common practice in the international celebrity press that has found its way into the Flemish press market. However, the interviewees disagreed on which party initiated this. The competition between the three magazines, as well as their strong position on the magazine market, forced the magazines to negotiate. For exclusive stories and photographs of babies or weddings, for instance, they have to reach a settlement with the celebrities involved, for example by offering to pay for decorating the baby's room, a honeymoon or foreign holiday. Of course, celebrities who are famous worldwide, like tennis player Kim Clijsters, have the strongest negotiating position. But other achieved celebrities also have a strong negotiating position. 'If I want to, I can go on a free holiday every day', said Natalia Druyts, Flanders' most popular singer.

Even when journalists ask celebrities to comment upon a negative private story before publication, they sometimes need to offer a cash deal. This involves the risk that if the deal is cancelled, the celebrity might offer the scoop to the competition. As a result, the journalists do not always ask celebrities for a response to a potentially harmful story that is about to be published.

Third, there is the technique of singling out one quote from an interview, almost always concerning the interviewee's private life and rarely representative of the whole article, to use as a headline. This was particularly blatant in the case of cover articles, where the spectacular quote on the cover often bore little relationship to the actual article. Kris Wauters, musician in Clouseau, Flanders' most popular pop group, gave the following example to illustrate this practice:

I once said in an interview with a reporter of Dag Allemaal, when he asked whether there were any babies in the making as Koen [his brother and lead singer of the band] already has two: 'No, but if we keep this interview short, I can go home to start one.' This provoked great hilarity! But the next week my picture was on the cover with the headline: 'Kris Wauters finally speaking frankly about his private life!' And then in big letters the quote: 'We plan to have a family soon!' That is exactly how it works.

A final characteristic by which the Flemish celebrity press differs from the foreign press concerns the relationship between the type of celebrities whose private lives were covered 
and the tone of the stories. The international celebrity press does not appear to be very selective: the bigger the star, the more likely that a private story will be published without his or her knowledge. This is not the case for the Flemish magazines: the stars with the highest status are usually treated with respect, whereas 'attributed' celebrities are more likely to end up on the cover without consent. Furthermore, the celebrities who gain sudden fame through reality programmes are particularly unable to control the kind of stories being published. While the show was running, they had already experienced what it felt like to appear on the cover of a magazine, sometimes several weeks in a row. Unfortunately, as soon as they quit the show or the programme comes to an end, the press starts digging up stories, for instance about their divorce, bankruptcy or dwindling success as a singer. These celebrities obtain celebrity status overnight, but they can lose it just as quickly. We noted that as soon as interest started to fade, the celebrity magazines tried to rekindle interest by publishing real gossip stories.

\section{The disposable celebrity}

The editors and journalists interviewed all indicated that the new celebrities created by reality shows were a godsend. While the shows ran, their news value was even greater than that of achieved celebrities, probably due to the audience's increased fascination with the mechanisms of celebrity production, the so-called 'hypertrophic celebrity culture' (Meyers 2010). As a result, newly minted celebrities adorned the magazine covers for almost the entire research period.

From the acknowledgment that they do not invest in building a long-standing relationship with these people, it emerged that the editors saw them as 'disposable celebrities'. The celebrity press seems to use - some would say abuse - them, but once the public loses interest, negative stories are no longer held back, and then it is over. 'I am eagerly looking forward to the arrival of the new My Restaurant Rules as that means new blood, new material and moreover material that has people's interest', said Story's editor-in-chief.

As emerged from the interview with this group of 'disposable celebrities', they enjoyed this sudden attention but were aware that they are easy prey for journalists. As one of the celebrities said: 'They use things you told them off-the-record or in a casual conversation. Of course, at these moments I say things I had not planned to mention.'

Other discussions revealed that journalists often put pressure on these celebrities: 'Either you talk to us or we will just make up an article ourselves', was a frequently used threat. It appeared, in other words, that in the case of 'disposable' celebrities, journalistic standards are routinely breached, mainly as a result of the uneven power balance between these celebrities and the press.

\section{Negative and 'private' stories sell best}

The decisions taken by editors-in-chief of celebrity magazines are mainly based on their experience of which covers sell best. This emerged from the temporary interest in reality show participants who are regularly the subject of cover stories. The editors are also aware that negative stories sell better than positive ones. The same goes for stories relating to a celebrity's private life. The editor-in-chief of TV Familie underlined the importance of the cover story as a principal marketing strategy (also noted by Marshall 2005): 
I will not deny that we present things more sensationally. That is my job, to attract the attention of people in the supermarket. An article has to sell; I have to reach my public. I have just one second to convince people on the basis of the cover.

The editors-in-chief established that readers' attention is drawn to negative stories. This trend towards negativity and sensationalism is strengthened because each weekly regularly publishes follow-up stories on news initiated by its competitors; that is, they tell a 'meta story' by picking up a story first published in another magazine. Story's editor-inchief stated that:

When, for example, Dag Allemaal has demolished someone, we offer him or her a platform the week after and an opportunity to tell their side of the story. If they have blown it with those local celebrities, they chase them into our camp [...] This is also the case the other way around.

\section{Negotiation and cooperation rather than conflict}

In line with Charron's (1989) typology, the relationship between celebrities and the press is mainly typified by negotiation. Further characterisation of the relationship, however, differs depending on the type of celebrity.

Achieved celebrities, for instance, are in a strong position, as they can negotiate on their own terms. Thus, television personality Marcel Vanthilt can afford to impose strict rules of conduct:

In a relationship, it is necessary to regularly show who is the boss. My relationship with the gossip press is really good now, in the sense that they finally understand that I only give interviews about TV programmes. So, this is a perfect mutual relationship, simply as there is in fact no relationship any more.

Other categories of celebrities, however, who really need the publicity offered by the celebrity press, are in a much weaker negotiating position. Given the magazines' huge readership - with Dag Allemaal in the lead - the editors are not always willing to offer free publicity, but insist on something in return. In this context, celebrity journalists refer to their journalistic identity: journalism is not advertising, whereas uncovering personal information about celebrities is part of the journalist's role: 'There are people who want to promote their CD but behave as louts; that bothers me, as respect should be mutual', said the editor-in-chief of TV Familie. In such cases, an agreement has to be reached in which, for example, a Flemish celebrity receives compensation, financial or in kind, for exclusive pictures in a domestic setting.

Attributed celebrities who are not currently involved in entertainment projects and depend on the magazines to remain in the spotlight have a much more limited margin for negotiation and need to rely on cooperation. These interviewees have to allow journalists access to their private lives and come up with suggestions for interesting stories: a photo shoot at home with the children, exclusive images of their holidays, photographs of their pregnant belly, and so forth. In return, the celebrity can count on a set of professional photographs that would look good in the family album.

The celebrities with short-term fame through participation in a reality show are in the weakest negotiation position and can only hope for mutual cooperation. Although the editors-in-chief argue that they treat them with respect, such short-lived celebrities are at the mercy of the press. According to Story's editor-in-chief: 
Honesty compels me to admit that the relationship is different. One is more respectful and patient with Koen Wauters [from pop group Clouseau], who is at the top, than with a singer who you think you will not need any more next year. This is an honest statement, isn't it? But, for example, woman farmer Conny [from the reality show Farmer Wants a Wife (2009)] [...] What we can do here, is just nicely portray, exclusively, her overweight daughters. But it is true that we can treat celebrities with a sell-by date differently.

As indicated above, the relationship between celebrities and the celebrity press can be characterised mainly as one of negotiation or cooperation rather than conflict. The interviewees themselves offered an explanation for this conclusion. First of all, Flanders is a small region with relatively few celebrity magazines on the market and a relatively small number of celebrities. Secondly, most celebrities can be easily approached for faceto-face or telephone interviews, unlike top celebrities from the US and UK, who are internationally renowned and hence less dependent on the national gossip press. In other words, it takes two to tango. Celebrity journalist Marc Coenegracht expressed this as follows:

In Flanders, we are condemned to work together. [...] We just have one drawer with ten big local celebrities, if we reject them, it is over. Abroad, they have ten drawers with ten celebrities in each one of them, so they can take many liberties. As the number of great stars is limited, we have to collaborate.

\title{
The credibility of celebrity news
}

In Flanders, the three magazines included in the research are not taken very seriously as news media, and neither are their journalists or readers. The journalists we interviewed therefore seized the opportunity to challenge a number of prejudices. For instance, Story's editor-in-chief said:

\begin{abstract}
We really are in a disadvantaged position due to the perception of the gossip press. This is because the other media benefit from depicting us as evil. VRT [national public television] and De Standaard [up-market broadsheet] gossip more than we do, or they spread more rumours and entertainment news on their websites than we do. I know their editors-in-chief of course and they know that we really try to proceed honestly and sincerely within our medium, our field. So, it is not the case that I am the pariah among editors-in-chief.
\end{abstract}

The journalists of the celebrity press argued that they maintain the same standards as journalists of the mainstream press, for instance by trying to provide objective and unbiased coverage and double-checking sources. Just like Deuze (2005), we found that the journalists constructed a professional identity during the discussions, among other things by insisting on journalistic ethics. It is for this reason that the Flemish celebrity press does not tend to carry the wild, made-up stories typical of some tabloids. These hard-to-believe stories would undermine the credibility of the Flemish celebrity journalists, who argue that they always double-check the facts, hear both sides of a story, and so forth. A tabloid such as The Sun has a bigger entertainment value than the Flemish celebrity press, which is clearly committed to publishing trustworthy celebrity news. The news they report is partly informative and partly related to the celebrities' private lives, under the pretext that it is the magazine's task to give the public a glimpse of the person behind the celebrity.

Content analysis suggests that the three magazines want to present themselves as trustworthy sources of celebrity news. They thus underline that they are "personal friends 
of the family'. For instance, certain reporters attend celebrity parties and feature in photographs about these events. Flemish magazines have the advantage that, as a rule, they can conduct private interviews, reproduced in question and answer format. The style of these interviews is informal, implying familiarity and a personal relationship between the celebrity and the journalist, who often call each other by their first names, for instance. Probably, this makes readers feel that they are part of a personal conversation and are privy to the celebrity's innermost feelings.

\section{Discussion}

Using a combination of a content analysis and interviews with both journalists and local celebrities, this paper has tried to gain greater insight into the relationship between celebrities and the Flemish celebrity press. Although this type of journalism has come in for harsh criticism lately, especially in serious press outlets, the definition 'gossip press' is less applicable to Flemish magazines than to certain foreign celebrity magazines and tabloids. Although press junkets have been organised for some years now, personal interviews remain the main source for the celebrity reporter in Flanders. An explanation for this finding can be found in the small size of the Flemish media and entertainment market. Given the limited number of media outlets and celebrities, both sides have no option but to rely on each other. Most journalists and celebrities label the mutual relationship as one of cooperation and negotiation.

Nevertheless, this cooperative relationship is coming under increasing pressure. As a result of fierce competition between the three magazines, television programmes, websites and other outlets offering celebrity news, journalists are constantly pushing the boundaries of what is deontologically acceptable. The editors-in-chief admit that they try to give readers 'what they want'; that is, scoops about celebrities' private lives. The criticisms that are frequently voiced and the conflicts with celebrities that regularly occur always turn on the central question of whether the media has the right to dig into celebrities' private affairs and to report on them, possibly without prior consent. As emerged from the present study, the journalists perceive their own work as proper journalism that meets all journalistic standards, even though the Flemish magazines are constantly pushing the boundaries in order to come up with exclusive celebrity news stories. A number of complaints have had no practical effect as they were later withdrawn by the celebrities in question, who probably realised that in the end press and celebrities depend on each other. Moreover, the attention devoted to these complaints in other media generated extra publicity, which boosted magazine sales while raising the celebrity's profile. This was often sufficient to achieve a reconciliation.

What may be more problematic is the magazines' cynical use of ordinary people who rise to unexpected fame through their participation in a reality show. For a while, these celebrities have more to offer than established celebrities, but as they have a limited sellby date, the celebrity press does not invest in building a long-term relationship. Hence, these celebrities have very limited negotiation leverage: once the public loses interest, they might still be the subject of some revealing cover story, but then they disappear from the spotlight. Celebrity status is increasingly short-lived (Kurzman et al. 2007).

In the case of achieved celebrities, all parties comply with the rules of engagement, which is characteristic of a negotiation relationship. Foreign celebrity magazines have already moved beyond that stage, with negotiation making way for a relationship of conflict. They constantly clash with celebrities, whereby photographers, journalists and publishers gain a lot of money from reporting private news to little or no advantage for the 
star in question. So far, the Flemish celebrity press has not adopted this model, although it regularly comes close. It seems to consider quite carefully which celebrities it can afford a conflict with, generally those whose fame is on the wane. More than ever, the press can both make and break a celebrity's career.

\section{Acknowledgements}

The author wishes to thank Els Van Herbruggen (MSc in Communication Science) and Suzanne Bastiaensen (MA in Journalism) for their collaboration on data-gathering and for insightful comments on earlier drafts of this paper.

\section{Notes}

1. While the winners of the Flemish series of Pop Idol (Idool) have quickly faded from the media spotlight, some of the other participants have gained celebrity status. For instance, Natalia Druyts, one of the interviewees in our 'achieved celebrity' category, was a runner-up in season one (2003) but has since become the most popular Flemish singer. In this article, I use the international names for the reality television formats rather than the Flemish versions (the Belgian television format The Mole (De Mol); the Australian television format My Restaurant Rules (Mijn restaurant); the British format Pop Idol (Idool); the British television format Farmer Wants a Wife (Boer zkt. vrouw)).

2. Most of the interviews, apart from van Raak, were conducted in spring 2010. Consequently, they date from before the July 2011 closure of the British tabloid News of the World as a result of the UK phone hacking scandal and the announcement in the same month of the Leveson Inquiry into the culture, practice and ethics of the press. See http://webarchive.nationalarchives. gov.uk/20140122145147/http:/www.levesoninquiry.org.uk/.

\section{Notes on contributor}

Baldwin Van Gorp ( $\mathrm{PhD}$, University of Antwerp) is associate professor of Journalism at the Institute for Media Studies at the University of Leuven, Belgium. From 1995 to 1999, before the start of his academic career, he was active as a freelance journalist, including for $t v$-Ekspres, a magazine that is mentioned in this paper. His research interests include, in addition to journalism, the concept of framing and communication management.

\section{References}

Belga, 2009. Pfaffs dienen klacht in tegen TV-Familie [Pfaff family institutes legal proceedings against TV-Familie] (press release 18 Sept. 2009) http://www.deredactie.be/permalink/1.600383 [Accessed 24 May 2014].

Big brother, 2000-2007. TV. Endemol for KanaalTwee.

Bird, S.E., 1992. For enquiring minds: a cultural study of supermarket tabloids. Knoxville, TN: University of Tennessee Press.

Cashmore, E., 2006. Celebrity/culture. New York: Routledge.

Centrum voor Informatie over de Media (CIM), 2011. Readership survey 2010-2011. Available from: http://www.cim.be [Accessed 2 April 2012].

Charron, J., 1989. Relations between journalists and public relations practitioners: cooperation, conflict and negotiation. Canadian journal of communication, 14 (2), 41-54.

Conboy, M., 2006. Tabloid Britain. New York: Routledge.

Cornea, C., 2008. Introduction: interviews in film and television studies. Cinema journal, 47 (2), $117-123$.

Curnutt, H., 2009. "A fan crashing the party": exploring reality-celebrity in MTV's real world franchise. Television \& new media, 10 (3), 251-266.

Dallas, 1978-1991. TV. Lorimar Productions for CBS.

De Foer, S., 2009. Helmut tegen Goliath [Helmut versus Goliath]. De standaard, 17 (Oct), 27-28. 
Deuze, M., 2005. What is journalism? Professional identity and ideology of journalists reconsidered. Journalism, 6 (4), 442-464.

DiFonzo, N. and Bordia, P., 2007. Rumor, gossip and urban legends. Diogenes, 54 (1), 19-35.

Farmer wants a wife [Boer zkt. vrouw], 2009. TV. FremantleMedia for VTM. 31 August 2009-16 November 2009.

Gorden, R.L., 1992. Basic interviewing skills. Long Grove, IL: Waveland Press.

Hauttekeete, L., 2004. De tabloidisering van kranten: mythe of feit? De ontwikkeling van een meetinstrument en een onderzoek naar de tabloidisering van Vlaamse kranten [The tabloidization of newspapers: myth or fact? The development of a measurement instrument and a study of the tabloidization of Flemish newspapers]. Thesis (PhD). Ghent University.

Kordon-Lundgren, C. and Kodron, C., 1976. 20000000 Unterm regenbogen: Zur inhaltsanalyse der regenbogenpresse. Munich: Carl Hanser Verslag.

Kurzman, C., et al., 2007. Celebrity status. Sociological theory, 25 (4), 347-367.

Levin, J. and Arluk, A., 1987. Gossip: the inside scoop. New York: Plenum Press.

Marshall, P.D., 2005. Intimately intertwined in the most public way: celebrity and journalism. In: S. Allen, eds. Journalism: critical issues. Maidenhead: Open University Press, 19-29.

Meyers, E.A., 2010. Reality television and the hypertrophic celebrity in Victoria Beckham: coming to America. Celebrity studies, 1 (3), 319-333.

Mills, B., 2008. After the interview. Cinema journal, 47 (2), 148-153.

My restaurant rules [Mijn restaurant], 2009. TV. Kanakna for VTM. 3 March 2009-2 June 2009.

Örnebring, H. and Jönsson, A.M., 2004. Tabloid journalism and the public sphere: a historical perspective on tabloid journalism. Journalism studies, 5, 283-295.

Ponce de Leon, C.L., 2002. Self-exposure: human-interest journalism and the emergence of celebrity in America, 1890-1940. Chapel Hill, NC: University of North Carolina Press.

Pop idol [Idool], 2003. TV. FremantleMedia for VTM. 3 January 2003-9 May 2003.

Rojek, C. 2001. Celebrity. London: Reaktion.

Roos, J.J., 1981. Bonheur-glück: Vermarktung des glücks in der französischen und deutschen press. Gerbrunn bei Würzbrug: Lehmann.

Rosenbaum, J.B. and Subrin, M., 1963. The psychology of gossip. Journal of the American psychoanalytic association, 11, 817-831.

Sparks, C., 2000. The panic over tabloid news. In: C. Sparks and J. Tulloch, eds. Tabloid tales. Lanham, MD: Rowman and Littlefield, 1-40.

The best hobby cook in Flanders [De beste hobbykok van Vlaanderen], 2009. TV. Kanakna for VTM. 1 September 2009-1 December 2009.

The mole [De mol], 2000. TV. Woestijnvis for VRT. 23 January 2000-19 March 2000.

The Pfaff family [De Pfaffs], 2002-2012. TV. Eyeworks for VTM.

The sixth sense [Het zesde zintuig], 2009. TéVéCompany for VTM. 3 September 2009-29 October 2009.

The X-files, 1993-2002. TV. Ten Thirteen Productions for Fox Television.

Turner, G., 2004. Understanding celebrity. London: Sage.

Turner, G., 2010. Approaching celebrity studies. Celebrity studies, 1, 11-20.

Van Zoonen, L., 1998. The ethics of making private life public. In: K. Brants, J. Hermes, and L. van Zoonen, eds. The media in question: popular cultures and public interests. London: Sage, 113-123.

Zoch, L.M., 2001. What's really important here?: media self-coverage in the Susan Smith murder trial. In: S.D. Reese, O.H. Gandy, and A.E. Grant, eds. Framing public life: perspectives on media and our understanding of the social world. Mahwah, NJ: Lawrence Erlbaum, 195-205. 


\section{Appendix 1. Interviewees}

Journalists

- Marc Coenegracht, celebrity journalist, Het Laatste Nieuws.

- Thomas Siffer, editor-in-chief, Story (until 2011).

- Isabelle Vandenberghe, editor-in-chief, TV Familie.

- Serge Vanhellemont, celebrity journalist, Dag Allemaal.

- Louis van Raak, editor-in-chief, Story (from 1975 to 2000).

\section{Celebrities}

- Claudia Allemeersch, winner of television show The Best Hobby Cook in Flanders [De beste hobbykok van Vlaanderen] (2009).

- Ignace Crombé, organiser of Miss Belgian Beauty.

- Staf Deboes, participant in Farmer Wants a Wife [Boer zkt. Vrouw] (2009).

- Sylvia De Laet, winner of television show The Sixth Sense [Het zesde zintuig] (2009).

- Tom Dice, singer and participant in the Eurovision Song Contest.

- Natalia Druyts, singer.

- Davy Gillis, actor.

- Hans Otten, TV personality

- Lindsey Pfaff, daughter of goalkeeper Jean-Marie Pfaff from reality show The Pfaff Family [De Pfaffs] (2002-2012).

- Mathias Sercu, actor.

- Gaëlle Six, winner of television show My Restaurant Rules [Mijn restaurant] (2009).

- Marcel Vanthilt, television personality.

- Wendy Van Wanten, television personality.

- Kris Wauters, musician in pop group Clouseau. 